\title{
Road Life Perspectives and Experiences among Iranian Truck Drivers: A Qualitative Study
}

\author{
Hussein Ranjbar ${ }^{1}$, Hossein Karimi Moonaghi ${ }^{2}$, Abbas Heydari ${ }^{3}$, \\ Seyed Reza Mazlom, Laura Scurlock-Evans ${ }^{5}$, Seyedeh Negar Assadi ${ }^{6}$ \\ ${ }^{1}$ PhD Student, School of Nursing and Midwifery, Mashhad University of Medical Sciences, Mashhad, Iran \\ ${ }^{2}$ Department of Medical Surgical Nursing, School of Nursing and Midwifery, \\ Mashhad University of Medical Sciences, Mashhad, Iran \\ ${ }^{3}$ Evidence-Based Caring Research Center, Department of Medical-Surgical Nursing, \\ School of Nursing and Midwifery, Mashhad University of Medical Sciences, Mashhad, Iran \\ ${ }^{4}$ Department of Medical Surgical Nursing, School of Nursing and Midwifery, \\ Mashhad University of Medical Sciences, Mashhad, Iran \\ ${ }_{5}^{5}$ sychological Sciences, University of Worcester, Henwick Grove, Worcester, WR2 6AJ, UK \\ ${ }^{6}$ Department of Occupational Health Engineering, Health Sciences Research Center \\ School of Health, Mashhad University of Medical Sciences, Mashhad, Iran
}

SUMMARY

Truck drivers are one of the largest occupational groups in Iran. Evidence from previous studies suggests that working and living conditions on the road engender many concerns for truck drivers, and their families and communities. This research aimed to explore the experiences of Iranian truck drivers regarding life on the road.

This qualitative study was conducted among Iranian truck drivers working in the inter-state transportation sector. A purposeful sample of 20 truck drivers took part in this research. Data were collected through semi-structured interviews and analyzed based on qualitative content analysis.

After analysis of the data, three main themes emerged: "Individual impacts related to the hardships of life on the road life", "Family impacts related to the hardships of road life", and "Having positive attitude towards work and road". These findings represent the dimensions of perspectives in the road-life of truck drivers.

Although truck drivers possess positive beliefs about their occupation and life on the road, they and their families face many hardships which should be well understood. They also need support to be better able to solve the road-life concerns they face. This study's findings are useful for occupational programming and in the promotion of health for truck drivers.

Key words: accidents, traffic, life, motor vehicles

Corresponding author:

Hossein Karimi Moonaghi

e-mail: Correspondinggroup@gmail.com 


\section{INTRODUCTION}

There are approximately half a million public carrier drivers working in Iran, of which nearly 306.000 are truck drivers. These drivers make up one of the largest occupational groups, and $92 \%$ of the goods transported in the country are conveyed by them (1). The number of this group drawn into this sector has been on the rise in the last several years so much so that the number of drivers grew dramatically from 137.000 drivers in 2006 to more than 300.000 in 2010.

In the absence of systematic management and prominent private carrier companies in the transportation network, the truck drivers who are mostly the owners of the vehicles personally oversee the loading and transport of goods via the cargo terminals and transport companies. Such a condition not only creates concerns and occupational hazards for the drivers, their families and community at large, but it also amplifies damage by increasing unnecessary conveyance resulting in an even higher rate of road hazards and by living on the roads for long stretches of time (2).

Truck driving is one of those occupational groups which are faced with a high level of physical and mental health challenges for living and working on the road (3-7). They usually experience conditions which can place them in risk of encountering problems in their lives, such as going on long trips, the absence of proper resting places and unsuitable facilities on the existing road (8-10). Moreover, working and living in low mobility status, night driving or non-stop and tiring driving, and a high calorie intake predispose truck drivers to metabolic syndromes and cardiovascular problems (11). The wear and tear of vehicles, poor condition of the roads and an increase in daily work hours are some of the factors related to working living environment makes the Iranian truck drivers encounter physical (12) and mental (9) health problems.

More than $25 \%$ of all truck driving accidents in Iran are due to the absence of proper sleeping places for drivers on long hauls; this means that a high proportion of road mishaps are influenced by drivers' living conditions on the road (13). Studies in other countries have shown that life conditions of truck drivers makes them come into contact with dangerous behavior such as having unhealthy sexual partners and drug abuse (14-17).

Therefore, the working and living conditions of truck drivers on the road engender many concerns, not only for the drivers themselves but also for their families, the consignment owners and the carrier companies (18). Thus, any action that aims to improve the present status requires research into the comprehension and perspective of the drivers regarding road life. Despite the importance of this issue, little is known of the perspectives and experiences of truck drivers with regard to life on the roads. Hence, a study on the living conditions of truck drivers on the road will carry many benefits, especially, for the driver themselves. As previous studies were mostly quantitative and focusing on one of the dimensions of the road life of truck drivers, they have been unable to shed ample light on the conditions and characteristics of their road life.

Human life has multiple dimensions and needs to be considered as a complex social phenomenon in any scrutiny (19). Furthermore, due to social and cultural differences, research carried out in other countries may be only slightly adaptable to the condition prevailing in our country (20). Thus, to cover the existing information gap, the present research was conducted to explore and describe the perspectives and experiences of Iranian truck drivers regarding road life.

\section{MATERIAL AND METHODS}

To explore and understand the perspectives of truck drivers about life on the road, qualitative content analysis was used. This method is mostly used to attain a broad and condensed description of human experiences. Moreover it can be used when the data is insufficient, incomplete or scattered (21) .

The participants in this study were 20 male, truck drivers, working in the inter-state transportation sector of Khorasan Razavi province, Iran. The inclusion criteria in this research were at least one year's truck driving experience, working in the interstate transportation sector, and having a voluntary willingness to take part in the study. In order to attain a variety of perspectives and experiences about the phenomenon under study and obtain richer data, sampling was carried out with maximum variation with regards to age, work experience and level of education. The participants recruited had a mean age of 48.00 years ( $\mathrm{SD}=9.77$ years), mean work experience of 20.25 years ( $\mathrm{SD}=10.18$ years) and diverse levels of education such as associate's degree, diploma, incomplete diploma, fifth grade and illiterate.

Purposeful sampling was used for data collection from truck drivers in this study, which is 
useful for gathering data from participants who have lived experience regarding the study phenomenon and the aims of the study. Data collection was undertaken with truck drivers using semi-structured interviews, with sessions ranging from 40-140 minutes in length. The interviews were conducted via interview guide comprised open-ended questions to allow participants to explain their experiences, example questions included: "Please briefly explain to me what it is like to work and live on the road or "How is the road life?" Follow-up questions were based on the information provided by the participants and were also focused on answering the main study question "What perspectives and experiences do truck drivers have of the road life?" In addition, the researcher also used probe questions to clarify participants' descriptions of the phenomenon of interest in the research. The interviews were conducted by the first author and recorded on a digital recorder.

Analysis was performed on the basis of Graneheim and Lundman's work of 2004, as follows (22): each interview considered as a unit of analysis was listened to several times accurately, and transcribed verbatim. During the process of analysis, units of meaning were identified from the texts and reproduced as condensed units of meaning. The condensed units of meaning were changed into abstract forms and recorded as codes. The codes changed into subcategories and categories using the constant comparison method, and based on their similarities and differences. Finally the latent meanings of the texts were developed as themes (se Table 1).

Table 1: Data analysis: example categories and sub-categories comprising themes

\begin{tabular}{|c|c|c|}
\hline Main theme & Category & Sub-category \\
\hline \multirow{9}{*}{$\begin{array}{l}\text { Individual impacts related to } \\
\text { hardships of life on the road }\end{array}$} & \multirow{3}{*}{ health-related problems } & physically-based issues \\
\hline & & mentally-based issues \\
\hline & & variable work conditions \\
\hline & \multirow[t]{3}{*}{ inappropriate work status } & working under time pressure \\
\hline & & working under time limits \\
\hline & & multiple responsibilities of work \\
\hline & \multirow[t]{3}{*}{ personal concerns } & work-related stress \\
\hline & & living away from home \\
\hline & & working and driving lonely \\
\hline
\end{tabular}

family concerns

Family impacts related to the

hardships of road life

health-related problems

family problems road traffic accidents

heavy family roles and responsibilities

physical effects of family members

mental effects of family members

living without head of the family

low family communication with relatives religious teachings

values and believes

family needs

personal interests

personal needs 
In this study, a few methods were used to determine the trustworthiness and rigor of the data. One of the methods used to increase the rigor of this study was peer checking, which was conducted by two PhD candidates of nursing. The data were coded and analyzed independently by the authors in this study and then were compared for findings: potential differences were resolved via group discussions. In order to be assured of trustworthiness, the findings also underwent member checking. Here, the transcripts of the dialogue were given to the participants to read for them to confirm whether the transferred concepts were true according to their experiences. Moreover, prolonged engagement of the researcher with the data and the phenomenon of the study was another way of making sure of trustworthiness of the findings.

The objectives and the benefits of the research were clearly explained to the participants and that participation was completely voluntarily and they could withdraw at any stage during the study. They were assured that their experiences would be kept confidential and that any sharing will be in an anonymous form and in the context of general findings. They were also assured that all audio records would be deleted after research work was complete. If the drivers accepted the explained terms, they would sign the related participation consent form for the interviews.

After analysis of data, three main themes emerged:" Individual impacts related to the hardships of life on the road life", "family impacts related to the hardships of road life" and "possessing a positive attitude toward work and road life". These findings explain the dimensions of perspectives of the drivers with regards to life on the roads, details of which are as follows:

Truck drivers account for a large portion of people in society who play an important role in turning the wheels of a country's economy. With a mere glance around us, we can easily see that nearly everything is somehow related to the hard work and services supplied by this large occupational group. Come rain or shine, even at times of the year when most of us can barely imagine going on a trip, this group is active on the road rendering service to us. Driving long-distances not only results in fatigue of the body and the mind, but also places the drivers in innumerable dangers that affect them, their families and society, which render them a vulnerable group. So much so that their individual and familial lives are directly affected by their working conditions and their life on the roads, dimensions of which certainly need to be explored further.

\section{Individual impacts related to the hardships of life on the road}

According to the participants, becoming a truck driver makes them spend most of their lives on the roads, leading to the development of health-related problems.

"Truck driving has made me fat and lazy. In the past, I used to play football; I would run for 120 minutes. Now ask me to run 5 steps, I can't." (Participant 2)"

The participants described their work on the road as an inappropriate wok status. They also cited other factors such as variable work conditions, road traffic accidents, working under time pressure, workrelated stress, time limits and the pressure for getting the job finished. They believed these items were important in causing hardship in road life.

"Most of the time, my load is fruit and vegetables, so I have to drive all night long in the winter to deliver the goods on time to the clients at the destinations. If I want to sleep on the way, the goods will get frozen, and if I'm unable to deliver on time, we must pay a fine." (Participant 4)

Another part of the individual hardships in the road life of truck drivers was related to their multiple tasks and responsibilities in life on the road. They were faced with these issues which they could not resolve easily.

"I am often faced with many responsibilities, not only do I have to worry about the condition of the tires and the engine, but also the loaders loading on time and things like that. Here I am, one driver, doing the jobs of 6, 7 people." (Participant 8)

The context and field of transportation is currently unsuitable and this itself makes another personal concern in the drivers' life on the roads, as such circumstances caused a lack of even basic necessities for drivers in the face of an emergency. Thus road life started becoming even more problematic for them, so much so that no longer felt positive towards it.

"Life on the roads does not have a good condition. If God forbid, we fall sick on the road. It's not like home. We ourselves must make our own food. We must come to terms with our sickness." (Participant 7) 


\section{Family impacts related to the hardships of road life}

As their work conditions may call for, the drivers might have to unintentionally drive for long and tiring stretches which may at times end in mishaps on the road. Such conditions create concerns for their families and do not allow these drivers to have peaceful family lives.

"From the moment we leave the house until the time we return home, our families call us several times. Reached? Not yet? They are always worried now that he has gone on the road, God forbid I hope he has not fallen asleep, his truck has not overturned..." (Participant 15)

Another part of the hardships of life for truck drivers' families is that some members of the family, especially mothers, have to play a heavier familial role. In fact, wives play a double role (both as a mother and as a father) in such families when the husband is absent. Forcing the mothers to take on more duties and a larger role in helping the fathers deals with the results from problems and hardships which arise from the occupation of driving and living on the road.

"Our womenfolk really do a manly job because they have to bring up three children and have a lot of duties with regards to training them."(Participant 2) "When I come home after a $2000 \mathrm{~km}$ drive, I am so tired I can hardly do anything else. So, my wife does the house work automatically..."(Participant 15)

One of the major worries of most of the participants in this research was that they spent little time bonding with their families. The occupation of truck driving usually includes living a life away from home.

"A driver like me who does not see his kids must go and unload first. As soon as I get home, I must go straight and load some goods. The moment I load, I have to leave town to deliver the goods. I am always wandering." (Participant 9)

Living and working in this occupational group leads to a condition in which the head of the family is mostly away from the family. This absence has a great influence on mental and emotional health of family members.

"I see my children are afraid to go into the yard at night. If we are in the bedroom and I ask them to bring me something from the hall, they are scared. I have told my wife several times not to lock all the doors. If an earthquake occurs, you all cannot get out. But because of the phobia they have, they lock everything ..." (Participant 5). "I have a small kid who won't let me leave for work, so I have to try several ways to trick him. One night when I had packed up my things to leave, I asked him, 'why don't you go to sleep son?' He said, 'if I do, you will leave.' That is why he was not ready to go to sleep ..." (Participant 19).

The truck drivers' absence from home and leaving other family members without head of the family during the life of family can also cause problems for these families, such as rarely having communication between family and their relatives.

"Most of the time I am not at home, so my family cannot go to meet relatives, weddings, death ceremonies or dinner parties. These poor creatures have sacrificed everything. There is no recreation for them, no going for drives, no festivals, no holidays, no religious ceremonies ..." (Participant 1)

\section{Possessing positive attitude toward work and road life}

Although road life has many concerns, problems and hardships of its own, following religious teachings, values and believes by the family was found to be an important and influential factor for most of the participants in this research. So much so that they had been able to easily accept all the hardships related to their work environment and, in an unexplainable way, they were proud to be strong believers. They even considered their individual and familial achievements and triumphs in life the fruits of their beliefs, and they were not ready to quit their job despite the hardships. This motivation enabled them to look at the problems and hardships of road life as minor issues and pass by them easily, and reach a state of mental peace.

"Life and work on the roads is enjoyable for me as I am able to take home 'halal' earnings [religiously clean and pure] and livelihood. I know I have to face a lot of trouble on the road, for example just last night, I got at home at 2 am and was back in the terminus at 7am. However, all this is very sweet for me. Its sweetness comes from the fact that it is 'halal'... (Participant 16) "I'm now aware of the fact that by the grace of God all my kids are safe and sound which is because I earn my bread according to our religious values. Bread which is earned through hardship has its effect on the family, too. All these things have influence..." (Participant 15)

Supplying the basic needs of their individual and family life was another subject that the truck drivers were occupied with. They considered driving and road life as an honorable way to earn a living; a 
job that leads to insurance of these needs for them and their families.

"I need to hit the road to make a living. Working on the highways has its own joy. A joy 'coz I can make money. So, if my wife wants to buy a certain thing, I do have money to buy it." (Participant 3)

The participants mentioned that facing the hardships and problems of road life do not have any negative impact on their life, but in fact they would be able to make the most out of that way of living to find the peace of mind. Thus, the truck drivers looked upon life on the road as part of their everyday lifestyle, to the extent that they addressed their basic and physiological needs while they are on the road. They believed if such personal interests and needs were not addressed then their more important basic needs such as individual security could be jeopardized.

"I have made life on the road to suit my taste, my personality and behavior. It is not very hard for me. I think to myself that at all times I am living my life; I mean, anyway, life is passing so I have made the road part of my everyday life. I do not mean that since I am on the road for a week, all else must be forgotten. Well, my going to and fro on the road is a kind of living, right? (Participant 8) "My wife and I were coming from Mashhad in a trailer truck, a few kilometers from home I felt groggy. I pulled over, took a ten minute nap and then we continued on our way home ..." (Participant 1)

\section{DISCUSSION}

One of the themes identified was the individual impacts related to the hardship of life on the road, and the difficulties and negative impacts these have on drivers' lives. The findings illustrate that for the drivers, life on the road has many effects, especially, healthrelated issues. Other researchers have also mentioned physical $(11,12,23)$ and mental problems (9) as some of the hardships that can be caused for Iranian truck drivers during their life on the roads. Further, the present study also showed inappropriate work status, time limits and work pressure at work, as the other difficulties in the individual life of truck drivers, and this is in line with previous study, which found these issues as occupational stressors of life truck drivers (4).

In our research, it was found that the number of responsibilities the truck drivers experienced had impacted greatly on their lives. The participants had not only to shoulder the duties related to the truck but also duties related to loading and unloading. In this way, both the individual and family life of the drivers would be affected by these roles. The number of duties the drivers had to manage is one of the more evident and unique findings of our research, which is the result of the prevailing condition of the transportation industry of the country.

In Iran at present, the drivers are not only considered as the truck owners but they also have to personally overlook all the tasks related to the transportation of goods, and so are the main professionals turning the wheel of the transportation sector. If strong transportation companies are established in this sector, they can take on all the activities related to check-ups and repairs of the vehicles, loading and unloading, and then the driver can do the single job he has of driving his truck. In such a situation, the driver can peacefully do his work and live his individual life on the road, and when he returns home, he can focus on the affairs of his family life until his next assignment begins. The unsuitable context and field of working in this occupation are other factors that make the individual life of a driver difficult. Some Iranian researches have also reported that a deficiency in the transport system and organizational management impacts on the condition of the individual life of truck drivers on the road $(9,24)$.

The second theme identified in this study related to how the hardships of road life affect the drivers' families. Previous studies have shown that life conditions of the truck drivers on the road and their being away from home reduces contact between family members; it makes communication among family members more difficult and brings about an extra responsibility of child rearing for the spouse or partner at home. On the whole, it makes survival of the family as a cohesive group more difficult, which has very crucial consequences in the life of the family truck drivers (18, 19). One study has shown that teens who have experienced life without the presence of fathers in families had greater anxiety and lower self-esteem when compared with other teens (19). In addition, the lifestyle of truck drivers also impose the responsibility of many home tasks (such as cleaning and child care) on their spouses (25).

The third theme that emerged in this research was having a positive attitude toward work and road life. The participants considered their work and life on the roads as the cause of peace of mind. They looked at their job as a means of doing good and as a (religiously) clean way to earn a livelihood, that had beneficial effects on their individual as well as family lives and causes 
spiritual peace for them. Further, they had adapted themselves to their life on the road in such a way that it was not very different with their daily life at home. Thus, this resulted in their not feeling tired of work and life, plus it has helped them reach peace and even reduce the problems in their lives. This finding was unique to the present research. Further studies are required to understand why this values and believes may exist.

\section{CONCLUSIONS}

Truck drivers possess positive and effective beliefs and values that help them to achieve peace and allow them to go about with their duty on the road in a better and more beneficial way. All these are related to their unique and specific cultural outlook and perspectives which have not been given enough attention and support. In view of the same, in order to be able to solve the problems on the road and eliminate the hardships they encounter, the drivers should be supported by other social systems. The findings of this research can be used in occupational programming and policy-making and in increasing the level of health in society, as a whole. We suggest more research of the qualitative method be done in this field.

\section{Limitations}

Although this research was carried out with maximum amount of variation in sampling, there were no truck drivers with academic level of education among the participants, so the research was executed on participants who had no college backgrounds. Therefore, the findings of this study may not be similar for drivers with college education. Thus, further research is needed to explore the role that level of education plays in defining the experiences and perspectives of Iranian truck drivers with regards to life on the roads.

\section{Conflict of Interest}

No potential conflict of interest relevant to this article declared.

\section{Acknowledgements}

This study is part of a PhD thesis that has been licensed by the Research Council of the Mashhad University of Medical Sciences (code no. 910379). The researchers have been supported by the management of the School of Nursing and Midwifery and that of the Mashhad University of Medical Sciences. We would like to thank them and also voice our gratitude to the authorities of the Head Office of Transportation, of the terminals in Khorasan Razavi Province and of the Road and Transport Office of the City of Torbat-e Heydarieh. Last but not the least we extend special thanks to the participants, without whose help, the research would not have been possible.

\section{Author Contributions}

H. Ranjbar designed the research, gathered and analyzed the data and wrote the preliminary draft of the manuscript. H. Karimi Moonaghi, A. Heydari, S.R. Mazloom and M. Bakhsi were involved in the analysis, conceptualization and interpretation of the data. L. Scurlock-Evans and S.N. Assadi revising the manuscript critically for important intellectual content. 


\section{References}

1. IRAN Road Maintenance \& Transport Organization.2010 [cited 19/8/2013]. Available from: http://www.rmto.ir/Pages/homepage.aspx.

2. IRAN Road Maintenance \& Transport Organization.2009 [cited 19/8/2013]. Available from: http://www.rmto.ir/Pages/homepage.aspx.

3. Reed DB, Cronin JS. Health on the road: issues faced by female truck drivers. AAOHN journal: AAOHNJ 2003;51(3):120.

4. Shattell M, Apostolopoulos Y, Sönmez S, Griffin M. Occupational stressors and the mental health of truckers. Issues Ment Health Nurs 2010;31(9):561-8.

http://dx.doi.org/10.3109/01612840.2010.488783

5. Wong WC, Tam SM, Leung PW. Cross-Border Truck Drivers in Hong Kong: Their Psychological Health, Sexual Dysfunctions and Sexual Risk Behaviors. JTravel Medicine 2007;14(1):20-30.

http://dx.doi.org/10.1111/j.1708-8305.2006.00085.x

6. da Silva-Júnior FP, de Pinho MSc RSN, de Mello PhD MT, de Bruin VMS, de Bruin PFC. Risk factors for depression in truck drivers. SOC PSYCH PSYCH EPID. 2009;44(2):125-9.

http://dx.doi.org/10.1007/s00127-008-0412-3.

7. Apostolopoulos Y, Sönmez S, Shattell M. Worksite-induced morbidities of truck drivers in the United States. AAOHN Journal 2010;58(7):285-96.

http://dx.doi.org/10.3928/08910162-20100625-01

8. Attarchi MS, Dehghan F, Seyedmehdi SM, Mohammadi S. Traffic accidents and related injuries in Iranian professional drivers. J Public Health 2012;20(5):499-503.

http://dx.doi.org/10.1007/s10389-011-0474-7

9. Vakili M, EslamiFarsani S, Hossein S, DehghaniTafti M. Prevalence of depression and its related factors among truck drivers in Yazd Province-2008. Iran Occupational Health 2010;6(4):69-76.

10. Fung CS, Wong WC, Tam MS. Familial and extramarital relations among truck drivers crossing the Hong Kong-China border. J Sex Marital Ther 2009;35(3):239-44. http://dx.doi.org/10.1080/00926230802716377

11. Saberi HR, Moravveji AR, Fakharian E, Dehdashti AR. Prevalence of metabolic syndrome in bus and truck drivers in Kashan, Iran. DIABETOL METAB SYNDR. 2011;3(1):1-5. http://dx.doi.org/10.1186/1758-5996-3-8

12. Karimi A, Nasiri S, Kazerooni FK, Oliaei M. Noise induced hearing loss risk assessment in truck drivers. Noise Health 2010;12(46):49. http://dx.doi.org/10.4103/1463-1741.59999

13. Halvani G, Nodoushan R, Nadjarzadeh A. Relation between road accidents and sleep quality of heavy vehicle drivers in Yazd. Int J Env Health Eng. 2012;1(1):40. http://dx.doi.org/10.4103/2277-9183.102374

14. Churi C, Anjenaya S, Churi C. Sexual behaviour among truck drivers halting at Kalamboli Truck Terminal, Navi Mumbai. Australasian Med J 2010;1(4):271-4.

http://dx.doi.org/10.4066/AMJ.2010.224

15. Pandey A, Benara SK, Roy N, Sahu D, Thomas M, Joshi DK, et al. Risk behaviour, sexually transmitted infections and HIV among longdistance truck drivers: a cross-sectional survey along national highways in India. Aids 2008;22:S81-S90.

http://dx.doi.org/10.1097/01.aids.0000343766.00573.15

16. Leyton V, Sinagawa D, Oliveira K, Schmitz W, Andreuccetti G, De Martinis B, et al. 
Amphetamine, cocaine and cannabinoids use among truck drivers on the roads in the State of Sao Paulo, Brazil. Forensic Sci Int. 2012;215(1):25-7. http://dx.doi.org/10.1016/j.forsciint.2011.03.032

17. Silva OA, Greve JM, Yonamine M, Leyton V. Drug use by truck drivers in Brazil. DRUGEDUC PREV POLIC. 2003;10(2):135-9. http://dx.doi.org/10.1080/0968763021000057727

18. Hill MJ, Hudson N, Lantz B, Griffin G. Commercial vehicle driver associate family issues assessment: Upper Great Plains Transportation Institute, North Dakota State University; 1997.

19. Luo J, Wang LG, Gao WB. The influence of the absence of fathers and the timing of separation on anxiety and self-esteem of adolescents: a cross-sectional survey. CHILD CARE HLTH DEV. 2012;38(5):723-31. http://dx.doi.org/10.1111/j.1365-2214.2011.01304.x

20. Özkan T, Lajunen T, Chliaoutakis JE, Parker D, Summala H. Cross-cultural differences in driving skills: a comparison of six countries. Accid Anal PrevAccid Anal Prev. 2006;38(5):1011-8. http://dx.doi.org/10.1016/j.aap.2006.04.006
21. Elo S, Kyngäs H. The qualitative content analysis process. J Advanced Nursing 2008;62(1):107-15. http://dx.doi.org/10.1111/j.1365-2648.2007.04569.x

22. Graneheim UH, Lundman B. Qualitative content analysis in nursing research: concepts, procedures and measures to achieve trustworthiness. Nurse Education Today 2004;24(2):105-12. http://dx.doi.org/10.1016/j.nedt.2003.10.001

23. Sadeghi N, Habibi E. The survey of relation between Musculoskeletal Disorders and Anthropometric Indices in the bus drivers in Isfahan. Iran Occupational Health 2009;6(1):6-14.

24. Khorasani-Zavareh D, Mohammadi R, Khankeh HR, Laflamme L, Bikmoradi A, Haglund BJ. The requirements and challenges in preventing of road traffic injury in Iran. A qualitative study. BMC Public Health 2009;9(1):486. http://dx.doi.org/10.1186/1471-2458-9-486

25. Lively C. In the Driver's Seat: Living and Working as a Trucker. 2010. 


\title{
Razmatranja stavova $i$ iskustva iranskih vozača kamiona: kvalitativna studija
}

\author{
Hussein Ranjbar ${ }^{1}$, Hossein Karimi Moonaghi², Abbas Heydari³ ${ }^{3}$ Seyed Reza Mazlom, \\ Laura Scurlock-Evans ${ }^{5}$, Seyedeh Negar Assadi ${ }^{6}$ \\ ${ }^{1}$ Student doktorskih studija, Fakultet za sestrinstvo i akušerstvo, \\ Univerzitet Medicinskih nauka Mashhad, Mashhad, Iran \\ ${ }^{2}$ Departman za medicnsko-hirurško sestrinstvo, Fakultet za sestrinstvo i akušerstvo, \\ Univerzitet Medicinskih nauka Mashhad, Mashhad, Iran \\ ${ }^{3}$ Centar za istraživanje nege zasnovane na dokazima, Departman za medicnsko-hirurško sestrinstvo, \\ Fakultet za sestrinstvo i akušerstvo, Univerzitet Medicinskih nauka Mashhad, Mashhad, Iran \\ ${ }^{4}$ Departman za medicnsko-hirurško sestrinstvo, Fakultet za sestrinstvo i akušerstvo, Univerzitet \\ Medicinskih nauka Mashhad, Mashhad, Iran \\ ${ }^{5}$ Psihološke nauke, Univerzitet $u$ Voršesteru, Henwick Grove, \\ Vorčester, WR2 6AJ, Velika Britanija \\ ${ }^{6}$ Departman za medicinu rada, Istraživački centar zdravstvenih nauka, \\ Medicinski fakultet, Univerzitet Medicinskih nauka Mashhad, Mashhad, Iran
}

\section{SAŽETAK}

Vozači kamiona su jedna od najvećih profesionalnih grupa u Iranu. Dokazi iz prethodnih studija ukazuju da radni I životni uslovi na drumu ugrožavaju vozače, njihove porodice kao i zajednice. Cilj ovog istraživanja bio je da ispita iskustva iranskih vozača u pogledu života na točkovima/drumu.

Ova kvalitativna studija je sprovedena među iranskim vozačima kamiona koji rade u međunarodnom transportnom sektoru. $U$ istraživanje je uključeno dvadeset vozača kamiona. Podaci su prikupljeni pitem polu-strukturiranih intervjua, a zatim interpretirani na osnovu kvalitativne analize sadržaja.

Nakon analize podataka, izdvojile su ste tri osnovne teme: “Lična pitanja povezana sa teškoćama života na drumu"; "Porodična pitanja povezana sa teškoćama života na drumu”; i "Pozitivni stavovi prema radu i životu na drumu". Ovi nalazi predstavljaju dimenzije razmatranja života na drumu iranskih vozača.

Premda iranski vozači imaju pozitivne stavove prema svom poslu i životu na drumu, oni, kao i njihove porodice, suočavaju se sa mnogim teškoćama koje treba pravilno razumeti. Njima je, takođe, potrebna podrška kako bi lakše savladali problem sa kojima se suočavaju na putu. Rezultati ove studije su korisni za izradu radnih programa, kao i za promociju zdravlja vozača kamiona.

Ključne reči: nesreće, saobraćaj, život, motorna vozila 